\title{
Some Characteristics of Cardinal Numerals between 2 and 19 in Karaim Bible Translations: New Results Based on New Karaim Materials
}

\author{
Zsuzsanna Olach
}

I gave one of my first academic talks at the International Conference on Turkish Linguistics organised by the University of Szeged in 2010. At the time I was still a doctoral student of Uppsala University. It was also the first occasion when Professor Róna-Tas had heard me speak on a scholarly topic. In that conference presentation, I discussed the characteristics of the numeral system found in a Halich Karaim Bible translation.

More than ten years later, I am delighted to have the honour of saluting Professor Róna-Tas on the momentous occasion of his goth birthday. Given the special nature of this event I have decided to investigate the same topic again. New and exciting research projects on Karaim Bible translations have provided us with access to fresh sources, as a consequence of which the Karaim numeral system, heavily influenced by the Hebrew numeral system, is worth a revisit. ${ }^{1}$ In this study, I will discuss the singular/plural markings on cardinal numerals 2-19 that appear in various Karaim Bible translations.

\section{Sources of the Study}

For the purposes of this discussion, I have made use of previously published Karaim translations (i.e. HKB, ADub.III.73 and the Crimean Karaim translations). In addition, however, I have also consulted a number of hitherto unpublished South-Karaim texts (TKow.o2, JSul.III.o1 and ADub.III.84).

1 Two Western Karaim sources used in this study have been edited within the framework of the research project KaraimBible [(Re)Constructing a Bible. A New Approach to Unedited Biblical Manuscripts as Sources for the Early History of the Karaim Language], which was funded by the European Research Council (ERC) within the European Union's Horizon 2020 research and innovation programme (grant agreement number 802645). I am grateful to my colleagues, Anna Sulimowicz-Keruth and Dorota Cegiołka, for providing me with their transcriptions of Books from JSul.III.o1 and ADub.III.84 before publication. 
One of the main texts to which I have referred in this study is the oldest known North-Western Karaim translation in print (catalogue number: ADub .III.73). The main part of the manuscript was copied and translated by Simcha ben Chananel in $1720 .{ }^{2}$ The text is vocalised, although the vocalisation signs were added at a later date by the copyist (Németh 2021: $5^{-6)} .^{3}$ The manuscript contains the Torah and The Five Megillot (Németh 2021: 4-5). ${ }^{4}$ The manuscript is part of the private collection of Aleksander Dubiński (Németh 2021: 8).

One of the South-Western Karaim sources (нкв) included in this study was originally analysed and partly edited by Olach (2013). The copyist was probably Jeshua Josef Mordkowicz (1802-1884) and the manuscript was in the possession of Amelija Abrahamowicz. It contains the Torah and the Haphtarot (Olach 2013:10-12).

Another text that was consulted was the South-Western Karaim translation of the Book of Chronicles (catalogue number TKow.o2). The manuscript contains the Former Prophets and $1-2$ Chronicles and was discovered recently in the private collection of Tadeusz Kowalski (Németh 2021: 16).

Yet another valuable source was the South-Western Karaim Torah translation (catalogue number JSul.III.o1) made by Jeshua Josef Mordkowicz (Németh 2021:15). In an annotation given at Exo. 30:34, Mordkowicz refers to Simcha ben Chananel. Hence, this translation was used to create JSul.III.o1 (Németh 2021: 7). The manuscript can be found in the private collection of Josef Sulimowicz.

Examples were also taken from the Book of Psalms as well as the Book of Nehemiah (catalogue number ADub.III.84) The translation was made by Jeshua Josef Mordkowicz and it contains the Ketuvim with the exception of 1${ }_{2}$ Chronicles (Németh 2021:16). The manuscript is kept in the private collection of Aleksander Dubiński.

As for the Eastern Karaim sources, the main texts analysed in this paper were those published by Jankowski et al. (2019). This publication incorporated several manuscripts kept in libraries and private collections together with the so-called Gözleve Bible (XVI-XX). Of the several translations comprising this group, BSMS 288 was the principal source for this volume. It was probably copied in the second half of the 18th century (Jankowski et al. 2019: XVI-XVII). This edition also includes the oldest Eastern Karaim translation (catalogue number JSul.III.02) which was copied by Abraham ben Samuel at the end of

2 Jeshua Josef Mordkowicz was the other copyist of the manuscript, but unidentified copyists contributed as well (Németh 2021: 7-8).

3 For those parts left unvocalised, see Németh 2021 (6).

4 For the missing folios, see Németh 2021 (5). 
the 17th century (Jankowski et al. 2019: XIX). ${ }^{5}$ Specific sources will be referred to in this study whenever needed.

It is well-known that nouns following cardinal numerals take the singular form in modern Turkic languages (Menges 1968: 118). However, in the case of Karaim the plural marking on an enumerated Hebrew noun was copied in Bible translations, i.e. the plural marking patterns in Karaim texts mainly follow the Hebrew original. Hence, the use of the plural marker and/or the demonstrative pronoun $o l$ 'that' performing the function of the definite article is governed by the rules of Hebrew grammar (Olach 2013: 120-133). In the following sections, the plural marking characteristics of cardinal numerals 2-19 that appeared in various Karaim Bible translations will be compared.

\subsection{Cardinal Numeral 2}

In the corpus, nouns modified by the numeral eki 'two' are in the singular if the corresponding Hebrew expression does not contain any numeral for 'two', but instead assumes a dual form of the noun (see also Olach 2013: 120-121). Since Karaim lacks a dual category, the translation of this Hebrew expression is a typical Turkic numeral construction, for instance, Biblical Hebrew: Exo.21:21 yômáyim [days.N:MASC.DUAL.ABs] 'two days', South-Western Karaim: н кв: Exo. 21:21 eki kin [two day] 'two days', JSul.III.o1: Exo. 21:21 eki kin [two day] 'two days', North-Western Karaim: ADub.III.73: Exo. 21:21 eki kün [two day] 'two days' (Németh 2021: 366), Crimean Karaim: Exo. 21:21 eki kün [two day] 'two days' (Jankowski et al. 2019: 126). ${ }^{6}$ Observe that the noun kin 'day' is in the singular. The same pattern occurs in the translation of Num. 9:22 yômáyim [days.N:MASC.DUAL.ABs] 'two days', thus South-Western Karaim: H KB: Num. 9:22 eki kin [two day] 'two days', North-Western Karaim: ADub.III.73: Num. 9:22 eki kün [two day] 'two days' (Németh 2021: 672), Crimean Karaim eki kün [two day] 'two days' (Jankowski et al. 2019: 240).

Different strategies can be observed in the translation of the same Hebrew dual form in the case of Num. 11:19 yômáyim [days.N:MASC.DUAL.ABs] 'two days'. Once again here South-Western Karaim and Crimean Karaim copyists/

5 JSul.III.O2 became available for research recently, as a consequence of which only the translation of the Book of Ruth published by Németh (2016) was consulted for the edition (Jankowski et al. 2019: XIX).

6 No examples can be found in JSul.III.02, ADub.III.84 and TKow.o2. 
translators used a noun in the singular: in South-Western Karaim: H KB: Num. 11:19 eki kin [two day] 'two days', JSul.III.o1: Num. 11:19 eki kün [two day] 'two days', in Crimean Karaim: Num. 11:19 eki kün [two day] 'two days' (Jankowski et al. 2019: 244). The North-Western Karaim translation, however, reflects this expression with a noun in the plural: ADub.III.73: Num. 11:19 eki kün:lar [two day:PL] 'two days' (Németh 2021: 680).

Similarly, the dual form of the Hebrew noun 'cubit' (Exo. 25:10 'ammātáyim [cubits.N:FEM.DUAL.ABS] 'two cubits') was translated into South-Western and Crimean Karaim with a numeral construction containing a noun in the singular: H Kв: Exo. 25:10 eki loqot da jarym [two cubit and half] 'two cubits and a half', JSul.III.o1: Exo. 25:10 eki loqot da jarym [two cubit and half] 'two cubits and a half', Crimean Karaim: Exo. 25:10 eki aršyn da jarym [two cubit and half] 'two cubits and a half' (Jankowski et al. 2019: 131). However, in the North-Western Karaim text a noun following such a numeral is in the plural: ADub.III.73: Exo. 25:10 eki loqot:lar da jarym [two cubit:PL and half] 'two cubits and a half' (Németh 2021: 380).

On the other hand, in Hebrew expressions containing the attributive numeral 'two', the noun is in the plural, for instance Exo. 25:12 $\hat{u}$ šatê tabbā $\mathrm{c} \underline{t}$ [two.CARD:FEM.DUAL.CONST. ring.N:FEM.PL.ABS] 'two rings', Lev. 5:7 štê tōrîm [two.CARD:FEM.DUAL.CONST. turtledove.N:FEM.PL.ABS] 'two turtledoves', Deut. 21:15 štê nāšìm [two.CARD:FEM.DUAL.CONST. wife.N:FEM.PL.ABS] 'two wives' (Waltke and O'Connor 1990: 276). Such expressions are translated into Karaim with the numeral 'two' and the plural form of the noun (see also Olach 2013: 122), for instance, South-Western Karaim: H K B: Exo. 25:12 eki izik:ler [two ring:PL] 'two rings', JSul.III.o1: Exo. 25:12 eki izik:ler [two ring:PL] 'two rings', North-Western Karaim: ADub.III.73: Exo. 25:12 eki jüzük:ler [two ring:PL] 'two rings' (Németh 2021:382), Crimean Karaim:Exo. 25:12 eki halqa:lar [two ring:PL] 'two rings' (Jankowski et al. 2019: 131). ${ }^{7}$ In the case of the other expressions, South-Western Karaim: н кв: Lev. 5:7 eki bedene:ler [two turtledove:PL] 'two turtledoves', JSul.III.o1: Lev. 5:7 eki bedene:ler [two turtledove:PL] 'two turtledoves', North-Western Karaim: ADub.III.73: Lev. 5:7 eki bedeńa:lar [two turtledove:PL] 'two turtledoves' (Németh 2021: 482), Crimean Karaim: Lev. 5:7 eki tor:lar [two turtledove:PL] 'two turtledoves' (Jankowski et al. 2019: 171); and

7 Similarly, the numeral 'two' and the noun in the plural can be found in the Crimean Karaim manuscript JSul.III.o2: Ru. 1:1 eki oglan:lar:y [two son:PL:POss3sG] 'his two sons' as the translational equivalent of Ru. 1:1 ûšnê b bānāyw [and two.CONJ.CARD:MASC.DUAL.CONST his sons.N:MASC.PL.CONST.SUFF:MASC3SG] 'his two sons' (Németh 2016: 169). In TKow.o2 ${ }_{2}$ Cr. 9:18 eki arslan:lar [two lion:PL] 'two lions', cf. Hebrew 2 Cr. 9:18 ûšənáyim 'ărāyôt [and two.CONJ.CARD:MASC.DUAL.ABS lions.N:MASC.PL.ABS] 'two lions'. 
South-Western Karaim: H KB: Deut. 21: 15 eki qatyn:lar [two wife:PL] 'two wives' and JSul.III.o1: Deut. 21:15 ekiqatyn:lar [two wife:PL] 'two wives', North-Western Karaim: ADub.III.73: Deut. 21:15 eki qatyn:lar [two wife:PL] 'two wives' (Németh 2021: 914), Crimean Karaim: Deut. 21:15 eki Xatyn:lar [two wife:PL] 'two wives' (Jankowski et al. 2019: 333).

In Biblical Hebrew, multiplicative expressions can be formed by means of the numeral in question. To express 'double, twice', either the cardinal numeral 'two', or its derived form, is used (Waltke and O'Connor 1990: 286-287). As the cardinal numeral is a dual form without a nominal element, Karaim translators/copyists resorted to a numeral construction as an equivalent. ${ }^{8}$ This is the Hebrew dual form in Neh. 13:20 ûstáyim [and two.N:FEM.DUAL.ABs] 'and twice' and in Ps. 62:12 štáyim [two.N:FEM.DUAL.ABs] 'twice' are rendered as ADub.III.84: Neh. 13:20 eki keret [two time(s)] 'twice (two times)' and ADub.II .84: Ps. 62:12 eki keret [two time(s)] 'twice (two times)' into South-Western Karaim: Gen. 27:36 pa ăămáyim [occurrences.CARD:FEM.DUAL.ABS] 'two occurrences', in South-Western Karaim: H KB: Gen. 27:36 eki keret:ler [two times: PL] 'twice' and JSul. III.o1: Gen. 27:36 eki keret:ler [two times:PL] 'twice', NorthWestern Karaim: ADub.III.72: Gen. 27:36 eki keret:lar [two times:PL] 'twice' (Németh 2021: 156), Crimean Karaim: Gen. 27:36 eki kerät:lär [two times:PL] 'twice' (Jankowski et al. 2019:43). Observe the plural forms in the Karaim translations, the only exception can be seen in ADub.III.84.

Another multiplication based on the cardinal numeral 'two' appears in Deut. 21:17 pî šanáyim [mouth.N:MASC.SG.CONST two.CARD:MASC.DUAL.ABS] 'two/ double portions'. Although the cardinal numeral in Hebrew is a dual form while the expression also contains a nominal element, its translational method is the same in all the Karaim Bible translations. That is, the Karaim translators/copyists made use of an interpretation as the equivalent of this Hebrew numeral expression by employing the word ilis/ülüš/paj 'portion' instead of the noun 'mouth': South-Western Karaim: н кв: Deut. 21:17 eki paj [two portion] 'two portions', JSul.III.o1: Deut. 21:17 eki ilis [two portion] 'two portions', North-Western Karaim: ADub.III.72: Deut. 21:17 eki ülüš [two portion] 'two portions' (Németh 2021: 914), Crimean Karaim: eki paj [two portion] 'two portions' (Jankowski et al. 2019: 333). ${ }^{9}$ Consider the singular form of the noun 'portion' and the difference between Hebrew and Karaim in the ordering of the elements.

8 No instances occur in JSul.III.O2.

9 What is remarkable is the difference in the lexicon, paj is used in нкв while ilis appears in JSul.III.or. 
2.2.1

Nominal in the Plural

In the case of the numerals from three to nineteen, the Hebrew enumerated noun is usually in the plural (Waltke and O'Connor 1990: 278-279). One such example is Exo. 25:33 šalōša $\bar{a}^{h} \bar{g} \partial \underline{b} \bar{\imath}^{-} \hat{\imath} m$ [three.CARD:MASC.SG.ABs bowls.N:MASC .PL.ABS] 'three bowls', which has been translated into Karaim with a numeral expression containing a noun in the plural (see also Olach 2013: 121-124). Thus, in South-Western Karaim: нкв: Exо. 25:33 ic cara:lar [three bowl:PL] 'three bowls', in JSul.III.o1: Exo. 25:33 ic cara:lar [three bowl:PL] 'three bowls', in North-Western Karaim: ADub.III.72: Exo. 25:33 üč čara:lar [three bowl:PL] 'three bowls' (Németh 2021: 382), in Crimean Karaim: Exo. 25:33 üč syrča:lar [three bowl:PL] 'three bowls' (Jankowski et al. 2019: 132). The plural suffix of the enumerated noun can also be seen in the following examples: Exo. 2:16 šébac bānôt [seven.CARD:FEM.SG.ABs daughters.N:FEM.PL.ABS] 'seven daughters', in South-Western Karaim: нкв: Exo. 2:16 jedi qyz:lar [seven daughter:PL] 'seven daughters', JSul.III.o1: Exo. 2:16 jedi qyz:lar [seven daughter:PL] 'seven daughters', in North-Western Karaim: ADub.III.72: Exo. 2:16 jedi qyz:lar [seven daughter:PL] 'seven daughters' (Németh 2021: 278), in Crimean Karaim: Exo. 2:16 jedi qyz:lar [seven daughter:PL] 'seven daughters' (Jankowski et al. 2019: 93); Num. 11:32 ăśārāa h̆ŏmārîm [ten.CARD:MASC.SG.ABs homers.N:MASC.PL.ABS] 'ten homers', in South-Western Karaim: нкв: Num. 11:32 on qupa:lar [ten homer:PL] 'ten homers', JSul.III.o1: Num. 11:32 on qupa:lar [ten homer:PL] 'ten homers', in North-Western Karaim: ADub.III.72: Num. 11:32 o[n] oba:lar [ten homer:PL] 'ten homers' (Németh 2021: 684), in Crimean Karaim: Num. 11:32 on oba:lar [ten homer:PL] 'ten homers' (Jankowski et al. 2019: 244); Biblical Hebrew: Deut. 1:23 šənêm 'āśār 'ănāšîm [two.CARD:MASC.DUAL.ABs ten.CARD: MASC.SG.ABS men.N:MASC.PL.ABS] 'twelve men', in South-Western Karaim: нкв: Deut. 1:23 on eki eren:ler [ten two man:PL] 'twelve men', JSul.III.o1: Deut. 1:23 on eki eren:ler [ten two man:PL] 'twelve men', in North-Western Karaim: ADub.III.72: Deut. 1:23 on eki eren:ler [ten two man:PL] 'twelve men' (Németh 2021: 818), in Crimean Karaim: Deut. 1:23 on eki kiši:lär [ten two man:PL] 'twelve men' (Jankowski et al. 2019: 295). ${ }^{10}$

10 The enumerated noun is also in the plural in ADub.III.84: Neh. 8:18 jedi kün:ler [seven day:PL] 'seven days' as the translation of Hebrew Neh. 8:18 šib at yāmîm [seven.CARD: MASC.SG.CONST days.N:MASC.PL.ABS] 'seven days', as well as in JSul.III.o2: Ru. 4:2 on kiši:lär [ten persons:PL] 'ten men' as the translational equivalent of Hebrew Ru. 4:2 ‘̌̌śărāa ${ }^{h}$ 'ănāšrim [ten.CARD:MASC.SG.ABS men.N:MASC.PL.ABS] 'ten men' (Németh 2016: 184). In TKow.o2, the noun generally is in the plural, e.g. 2 Cr. 7:9 jedi kin:ler [seven day:PL] 'seven days' as the translation of Hebrew 2 Cr. $7: 9$ šib́at yāmîm [seven.CARD:MASC.SG.CONST days.N:MASC.PL.ABS] 'seven days'. 


\subsubsection{Nominal in the Singular}

A noun following a cardinal numeral can take the singular form in Hebrew when the word is a collective noun or a word of time, weight or measure

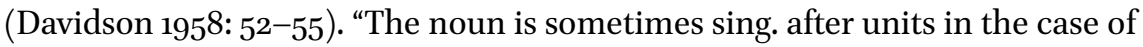
words used collectively, $[. .$.$] and in cases where the thing weighed or measured$ is omitted" (Davidson 1958: $5^{2}$ ); for instance, a noun used collectively after a numeral can be attested in Exo. 21:37 hִămišš $\bar{a}^{h} \underline{b} \bar{a} q \bar{a} r$ [five ox:N:MASC.SG.ABS] 'five oxen', in Exo. 21:37 wa'arba'șō'n [and four sheep:N:Bot H.SG.ABs] 'and four sheep' and in 2 Cr. 4:4 'al-šənêm 'āśār bāqār [on two.PREP.CARD:MASC.DUAL .ABS ten.CARD:MASC.SG.ABS ox.N:MASC.SG.ABS] 'on twelve oxen'. In such cases, the Karaim translations reflect the original Hebrew properties and use nouns in the singular following the cardinal numerals. Hence, translations of the above-mentioned examples into Karaim are as follows: South-Western Karaim: нкв: Exо. 21:37 bes syg்yr [five oxen] 'five oxen' and Exo. 21:37 dert qoj [four sheep] 'four sheep', JSul.III.o1: Exo. 21:37 bes syg்yr [five oxen] 'five oxen' and Exo. 21:37 dert qoj [four sheep] 'four sheep', and TKow.02: 2 Cr. 4:4 on eki syg்yr istine [twelve oxen on] 'on twelve oxen'; North-Western Karaim: A.Dub.III.73: Exo 21:37 beš syg்yr [five oxen] 'five oxen' and Exo. 21:37 dört qoj [four sheep] 'four sheep' (Németh 2021:368), Crimean Karaim: Exo. 21:37 beš syg்rr [five oxen] 'five oxen' and Exo. 21:37 dört qoj [four sheep] 'four sheep' (Jankowski et al. 2019: 295). ${ }^{11}$

\subsubsection{Fluctuation in the Number of Nominals}

Since the singular and plural forms of nouns in numeral expressions can fluctuate in Hebrew (Davidson 1958:54), the same is accordingly true of Karaim trans-

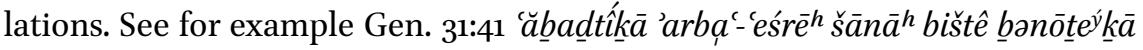
wəšēš šānîm bașōnéḱā [serve:v:QAL.PRF.1SG.SUFF:MASC.2SG four-ten year:N: FEM.SG.ABS for two:PREP.N:CARD.FEM.DUAL.CONST your daughters:N:FEM. PL.CONST.SUFF:MASC.2SG and six years:N:FEM.PL.ABS your flock:N:BOTH.SG. CONST.SUFF:MASC.2SG] 'I served you fourteen years for your two daughters, and six years for your flock' and its renderings: South-Western Karaim: нкв: Gen. 31:41 qulluq et:ti:m sana on dert jyl eki qyz:lar:yn icin da alty jyl:lar qoj:un icin [serve:DI.PST.1SG you:DAT ten four year two daughter:PL.POSS2SG for and six year:PL flock:POss2SG for] 'I served you fourteen years for your two daughters, and six years for your flock', JSul.III.o1: Gen. 31:41 qulluq et:ti:m sana on dertjyl eki qyz:lar:yn ücün da alty jyl:lar qoj:un ücün [serve:DI.PST.1SG you:DAT ten four year two daughter:PL.POsS2SG for and six year:PL flock:POsS2SG for]

11 No proper examples can be found in ADub.III.84 and JSul.III.o2. 
'I served you fourteen years for your two daughters, and six years for your flock', North-Western Karaim: ADub.III.73: Gen. 31:41 qulluq et:ti:m saja [o]ndört jyl eki qyz:lar:yj üčün da alty jyl:lar qoj:uj üčün [serve:DI.PST.1SG you:DAT ten four year two daughter:PL.POSS2SG for and six year:PL flock:POSS2SG for] 'I served you fourteen years for your two daughters, and six years for your flock' (Németh 2021: 178), Crimean Karaim: Gen. 31:41 qulluq et:ti:m saya on dört jyl eki qyz:lar:yn učun da alty jyl:lar qoj:yy učyn [serve:DI.PST.1SG you:DAT ten four year two daughter:PL.POSS2SG for and six year:PL flock:POSS2SG for] 'I served you fourteen years for your two daughters, and six years for your flock' (Jankowski et al. 2019: 52). Consider the singular form of the noun jyl 'year' following the numeral 'fourteen' and its plural form after the numeral 'six'.

In the Book of Numbers, the Hebrew noun 'day' is expressed in the plural after the numerals 'five' and 'ten', but is in the singular when following

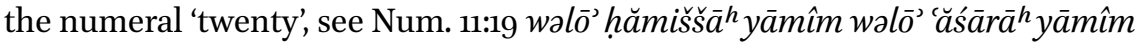
walō' 'érrîm yôm [and not five:CARD.MASC.SG.ABS days:N.MASC.P L.ABS and not ten:CARD.MASC.SG.ABS days:N:MASC.PL.ABS and not ten: CARD.MASC.PL.ABS day:N:MASC.SG.ABS] 'and not five days and not ten days and not twenty days'. South-Western Karaim: н к B: Num. 11:19 ani tivil bes kin:ler ani tivil on kin:ler ani tivil egirmi kin [or not five day:PL or not ten day:PL or not twenty day] 'or not five days or not ten days or not twenty days', JSul.III.o1: Num. 11:19 ani tivil bes kün:ler ani tivil on kün:ler ani tivil egirmi kün [or not five day:PL or not ten day:PL or not twenty day] 'or not five days or not ten days or not twenty days', North-Western Karaim: ADub.III.73: Num. 11:19 da tüvül beš kün:lar da tüvül on kün:lar da tüvül igirmi kün [and not five day:PL and not ten day:PL and not twenty day] 'and not five days and not ten days and not twenty days' (Németh 2021: 680), Crimean Karaim: Num. 11:19 da dügül beš kün da dügül on kün da dügül jigirmi kün [and not five day and not ten day and not twenty day] 'and not five days and not ten days and not twenty days' (Jankowski et al. 2019: 244). Interestingly, the NorthWestern Karaim and the Crimean Karaim translations maintain the original Hebrew conjunction whereas the South-Western Karaim translations provide an interpretation with the use of ani 'or, neither'. As for the number of the noun, most of the translations with the exception of the Crimean Karaim text follow the Hebrew singular and plural forms of the noun. In the Crimean Karaim corpus, on the other hand, the numerical expression displays Turkic characteristics, i.e. the enumerated noun is always in the singular after the numeral. ${ }^{12}$

12 Note that the original Hebrew noun is in the plural; however, in the Crimean Karaim translation the Karaim translator used an enumerated noun in the singular instead JSul.III.o2, 
Davidson notes that the measure 'cubit' in Hebrew is often used in the plural (1958: 54), for example in Exo. 36:15 wa'arba 'ammôt róh hab hayarî́a ${ }^{h} h \bar{a}^{\prime} e \underline{a} \bar{a} \underline{t}$ [and four.CARD:FEM.SG.ABS cubit.N:FEM.PL.ABS breadth.N:MASC.SG.CONST the curtain.DEF.N:FEM.SG.ABS the one.DEF.N:FEM.SG.ABS] 'and four cubits was the breadth of one curtain' and in 2 Cr. 4:1 wəéśer 'ammôt qômātô [and ten .CONJ.CARD:FEM.SG.CONST cubit.N:FEM.PL.ABS its height.N:FEM.SG.CONST .SUF F:MASC $3 \mathrm{SG}$ ] 'and ten cubits (is) its height'. In such cases, the Karaim translations feature plural forms as well, South-Western Karaim: H KB: Exo. 36:15 dert loqot:ler kenlig:i ol bir en:nin [four cubit:PL breadth:POss3SG that one curtain:GEN] 'four cubits was the breadth of one curtain', JSul.III.o1: Exo. 36:15 dert loqot:ler kenlig:i ol bir en:nin [four cubit:PL breadth:POss3SG that one curtain:GEN] 'four cubits was the breadth of one curtain', TKow.02: 2 Cr. 4:1 da on loqot:lar turu:su anyn [and ten cubit:PL height:POsS3SG it:GEN] 'and ten cubits (is) its height'; North-Western Karaim: ADub.III.73: Exo. 36:15 dört loqot:lar kenlig:i ol bir en:nin [four cubit:PL breadth:POsS3SG that one curtain:GEN] 'four cubits was the breadth of one curtain' (Németh 2021: 440). The only exception once again is the Crimean Karaim translation where the singular form can be found: Crimean Karaim: Exo. 36:15 dört aršyn bilän keylik:i ol bir biz:niך [four cubit with breadth:Poss3sG that one curtain:GEN] 'with four cubits was the breadth of one curtain' (Jankowski et al. 2019:155).

Besides the typical plural form of 'cubit', the form $b \bar{a}^{3} a m m \bar{a}^{h}$ [in the cubit .PREP.DEF.N:FEM.SG.ABS] 'in the cubit' became "common in later style" (David-

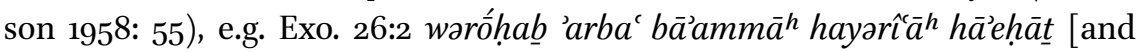
breadth.CONJ.N:MASC.SG.ABS four.CARD:FEM.SG.ABS in the cubit.PREP.DEF.N: FEM.SG.ABS the curtain.DEF.N:FEM.SG.ABS the one.DEF.N:FEM.SG.ABS] 'and the breadth of one curtain four cubits' and 2 Cr. 4:2 éser b $b \bar{a}^{3} a m m \bar{a}^{h}$ [ten.CARD .FEM.SG.ABS in the cubit.PREP.DEF.N:FEM.SG.ABS] 'ten cubits'. The Karaim translations render this special form with the noun in the singular, i.e. SouthWestern Karaim: н кв: Exo. 26:2 da kenlik dert loqot byla ol bir en [and the breadth of four cubit with that one curtain] 'and the breadth of one curtain four cubits', JSul.III.o1: Exo. 26:2 da könlik dert loqot byla ol bir en:nin [and the breadth of four cubit with that one curtain:GEN] 'and the breadth of one curtain four cubits', TKow.02:2 Cr. 4:2 on loqot byla [ten cubit with] 'with ten cubits'; North-Western Karaim: ADub.III.73: Exo. 26:2 da kenlig:i dört loqot ol bir en:nin [and breadth:POss3sG four cubit that one curtain:G EN] 'and the breadth of one curtain four cubits' (Németh 2021: 386), Crimean Karaim: Exo. 26:2 da keylig:i

see Hebrew Ru. 1:4 kəéśser šānîm [about ten.PREP.CARD:FEM.SG.CONST years.N:FEM.PL .ABS] 'about ten years', JSul.III.o2: Ru. 1:4 on jyl [ten year] 'ten years' (Németh 2016: 170). 
dört aršyn bilän ol bir bez:niy [and breadth:POss3SG four cubit with that one curtain:GEN] 'and the breadth of one curtain four cubits' (Jankowski et al. 2019: 133). It should be noted that definitude is not denoted in this case by means of the demonstrative pronoun $o$ ' 'that'.13

\subsubsection{Omission}

A number of measure words are omitted in the Hebrew Bible (Davidson 1958: 54-55), for instance, the word 'shekel' is missing in Gen. 24:22 'ǎśa $\overline{r a}^{h} z \bar{a} h \bar{a} \underline{b}$ [ten gold:N:MASC.SG.ABS] 'ten (shekels) gold'. Most of the Karaim translations feature this characteristic, e.g. South-Western Karaim: H K B: Gen. 24:22 on altyn [ten gold] 'ten gold', JSul.III.or: Gen. 24:22 on altyn [ten gold] 'ten gold', NorthWestern Karaim: ADub.III.73: Gen. 24:22 on altyn [ten gold] 'ten gold' (Németh 2021: 368). However, the Crimean Karaim copyists/translators provide an interpretive translation by adding the word misqal 'shekel' to the numeral expression, see Crimean Karaim: Gen. 24:22 on misqal altyn [ten shekel gold] 'ten shekels gold' (Jankowski et al. 2019: 35$){ }^{14}$

Though not typical measure words, some terms clearly performing the function of a unit have been added to the text in TKow.O2 where the Hebrew original has no equivalent for the expression. For instance, in Hebrew only the number 'four' occurs in verse ${ }_{1} \mathrm{Cr}$. 3:5 'And these were born unto him in Jerusalem; Shimea, and Shobab, and Nathan, and Solomon, four' ( 1 Cr. 3:5 'arb $\bar{a}^{c} \bar{a}^{h}$ [four.CARD:MASC.SG.ABS] 'four'), but in TKow.o2 the word 'son' is added as well (TKow.o2: 1 Cr. 3:5 dert uvul [four son] 'four sons').

We have, however, some counterexamples as well. The Hebrew word 'measure' is omitted again in Ru. 3:15 šěšśšôrîm [six.CARD:FEM.SG.CONST barley: N:FEM.PL.ABS] 'six (measures of) barley', but the Karaim copyists/translators preferred to add the word 'measure' to provide an intelligible Karaim text, e.g. North-Western Karaim:ADub.III.73: Ru. 3:15 alty ölčov ol arpa:lar:ny ošpu:lar:ny [six measure that barley:PL:ACC that: PL:ACC] 'the six measures of barley (ACC)' (Németh 2015: 70), Crimean Karaim: Ru. 3:15 alty ölčä arpa [six measure barley] 'six measure barley' (Jankowski et al. 2019: 370), JSul.III.o2 alty \{ošbu ölčä arpa:ny\} [six that measure barley:ACC] 'the six measures of barley (ACC)' (Németh 2016: 183). Consider the occurrence of the demonstrative pronoun оšpu 'that' in ADub.III.73 and ošbu 'that' in JSul.III.o2 and the accusative

13 This is probably due to the combination of the prefix and the definite article in Hebrew. The definite article has no translational equivalent in Karaim when it is combined with a prefix (Olach 2013: 70-71).

14 No instances or counterexamples can be found in ADub.III.84. 
form of the noun arpa:lar:ny 'barley (PL:ACC)' / arpa:ny 'barley (ACC)' in the North-Western Karaim manuscript and in one of the Crimean Karaim texts.

\section{Conclusions}

Overall, the new Karaim materials confirm earlier observations regarding the translational methods applied to Hebrew numeral expressions containing number 2-19. Thus, the translational equivalent of a Hebrew dual form is a numeral expression containing the numeral 'two' and the noun in the singular. However, the oldest North-Western Karaim text includes exceptional cases as well, with the noun sometimes following the numeral.

Furthermore, new characteristics can also be detected. For instance, in the Karaim translations of multiplicative expressions based on the Hebrew numeral 'two' (i.e. 'twice'), a noun is inserted which is usually in the plural (keretler, keretĺar, kerätlär). However, in the South-Western Karaim ADub.III .84 , the nominal is actually in the singular (keret). Another Hebrew multiplicative expression is translated into all Karaim varieties with a numeral expression containing a noun in the singular (paj, ilis, ülüs). In this case, the Hebrew original has a noun in the singular, too. See also Table 9.1.

TABLE 9.1 Rendering of dual forms into Karaim

\begin{tabular}{lll}
\hline & Singular & Plural \\
\hline Dual forms & H KB (SWKar) & \\
& ADub.III.73 (NWKar) & ADub.III.73 (NWKar) \\
& CrKar & \\
Multiplicative expressions—- & ADub.III.84 (SWKar) & HKB (SWKar) \\
Dual forms without nominals & & JSul.III.o1 (SWKar) \\
& & ADub.III.73 (NWKar) \\
Multiplicative expressions- & H KB (SWKar) & CrKar \\
Dual forms with nominal & JSul.III.o1 (SWKar) & \\
& ADub.III.73 (NWKar) & \\
& CrKar & \\
\hline
\end{tabular}


The publication of new sources has enabled identification of further characteristics of numerals from 3 to 19 . As was previously noted, nouns usually take the plural form after numerals 3 to 19 . However, nominals in the singular can also be found. Moreover, variations can be attested as well, i.e. while nouns are, for the most part, expressed in the plural, they sometimes also appear in the singular.

Although words of measure are generally in the plural, in one specific form ( $b \bar{a} m m m \bar{a} h)$ they are in the singular. For the most part the Karaim translations follow the Hebrew original patterns for singularity/plurality. The one exception is the Crimean Karaim texts, where the singular forms are more often applied.

Measure words tend to be omitted in Biblical Hebrew. The translational strategy of Karaim copyists/translators was not consistent in such cases. For example, measure words are sometimes omitted, but often they additionally appear in Karaim translations.

\begin{tabular}{llll}
\multicolumn{5}{c}{ Abbreviations } & & \\
1 & first person & FEM & feminine \\
2 & second person & GEN & genitive \\
3 & third person & MASC & masculine \\
ABS & absolute state & N & noun \\
ACC & accusative & PL & plural \\
BOTH & common gender & POSS & possessive \\
CARD & cardinal numeral & PREP & preposition \\
CONJ & conjunction & PRF & perfect \\
CONST & construct state & QAL & verb form qal \\
DAT & dative & SG & singular \\
DEF & definite article & SG & singular \\
DI.PST & past in $-D I$ & SUFF & suffix \\
DUAL & dual & V & verb
\end{tabular}

\section{References}

Davidson, Andrew Bruce. 1958. An introductory Hebrew grammar. Hebrew syntax. 3rd edition reprinted. Edinburgh: T and T Clark.

Jankowski, Henryk; Aqtay, Gulayhan; Cegiołka, Dorota; Çulha, Tülay and Németh, Michał. 2019. The Crimean Karaim Bible. Critical edition of the Pentateuch, Five Scrolls, 
Psalms, Proverbs, Job, Daniel, Ezra and Nehemiah. Volume 1. (Turcologica 119). Wiesbaden: Harrassowitz Verlag.

Menges, Karl H. 1968. The Turkic languages and peoples. An introduction to Turkic studies. (Ural-Altaische Bibliothek 15). Wiesbaden: Harrassowitz.

Németh, Michał. 2015. An early North-Western Karaim Bible translation from 1720. Part 2. The Book of Ruth. Karaite Archives 3: 49-102.

Németh, Michał. 2016. A Crimean Karaim handwritten translation of the Book of Ruth dating from before 1687 . Another contribution to the history of Crimean Karaim and to the question of the stemma codicum of the Eupatorian printed edition of the Tanakh from 1841. Türk Dilleri Araştırmaları 26/2: 161-226.

Németh, Michał. 2021. The Western Karaim Torah. A critical edition of a manuscript from 1720. Volume 1. (Languages of Asia 24). Leiden and Boston: Brill.

Olach, Zsuzsanna. 2013. A Halich Karaim translation of Hebrew biblical texts. (Turcologica 98). Wiesbaden: Harrassowitz.

Waltke, Bruce K. and O'Connor, Michael. 1990. An introduction to Biblical Hebrew syntax. Winona Lake: Eisenbrauns. 